\title{
KEBERFUNGSIAN SOSIAL BAGI MAHASISWA PENYALAHGUNA NEW PSYCHOACTIVE SUBSTANCE DI UNIVERSITAS PADJADJARAN
}

\author{
OLEH: \\ MAILY VINTAN, DESSY HASANAH SA, MAULANA IRFAN \\ 1. Mahasiswa Program Studi Sarjana (S-1) IImu Kesejahteraan Sosial IImu Sosial dan IImu Politik Universitas Padjadjaran \\ 2. Pusat Studi Kesejahteraan Anak dan Keluarga Fakultas IImu Sosial dan Ilmu Politik Universitas Padjadjaran \\ 3. Pusat Studi Kesejahteraan Anak dan Keluarga Fakultas IImu Sosial dan IImu Politik Universitas Padjadjaran
}

Email:

(maily14001@mail.unpad.ac.id, dessyhasanenoch@gmail.com, sangirfan@gmail.com)

\begin{abstract}
ABSTRAK
Saat ini, muncul fenomena baru dalam bidang narkotika. Ada jenis baru yang disebut dengan New Psychoactive Substance atau NPS. NPS merupakan narkotika yang tidak tercantum dalam Single Convention on Narcotics Drugs tahun 1961 atau Single Convention on Psychotropics Substances tahun 1971 oleh UNODC. Di Indonesia, beberapa jenis NPS dicantumkan oleh Kementrian Kesehatan dalam Permenkes no 02 tahun 2017 dan Permenkes no 03 tahun 2017 tentang penambahan daftar lampiran undang-undang narkotika dan psikotropika. Dengan beredarnya NPS di Indonesia, maka ada berbagai macam efek yang ditimbulkan, temasuk ancaman kesehatan, efek psikologis dan ancaman bahaya lainnya. Berdasarkan kajian tersebut, maka muncul sebuah penelitian mengenai penggunaan NPS di kalangan mahasiswa di Universitas Padjadjaran. Penelitian ini menggunakan beberapa konsep, yaitu mengenai NPS, permasalahan NPS di Indonesia, dan dampak dari NPS tersebut. Metode yang digunakan dalam penelitian ini adalah melalui pendekatan kualitatif dengan metode deskriptif. Penelitian bertujuan untuk mengetahui mengenai keberfungsian sosial bagi penyalahguna NPS. Adanya fenomena mengenai penyalahgunaan NPS menjadi alasan dipilihnya kualitatif sebagai suatu metode yang digunakan untuk penelitian ini.
\end{abstract}

\begin{abstract}
Currently, there is a new phenomenon in the field of narcotics. There is a new type called New Psychoactive Substance or NPS. NPS is a narcotics not listed in the 1961 Single Convention on Narcotics Drugs or Single Convention on Psychotropics Substances of 1971 by UNODC. In Indonesia, several types of NPS are listed by the Ministry of Health in Permenkes no 02 of 2017 and Permenkes no 03 of 2017 on the addition of lists of attachments to narcotics and psychotropic laws. With the distribution of NPS in Indonesia, there are various effects, including health threats, psychological effects and other hazards. Based on this study, a study appears on the use of NPS among students at Padjadjaran University. This study uses several concepts, namely on NPS, NPS problems in Indonesia, and the impact of the NPS. The method used in this research is through qualitative approach with descriptive method. The study aims to find out about social functioning for NPS abusers. The existence of the phenomenon regarding misuse of NPS became the reason for choosing qualitative as a method used for this research.
\end{abstract}




\begin{tabular}{|l|l|l|l|l|}
\hline Jurnal Penelitian \& PKM & Juli 2017 & Vol 4, No: 2 & Hal: $129-389$ & ISSN \\
\hline
\end{tabular}

\section{Pendahuluan}

Beredarnya jenis narkotika baru di dunia menjadi sebuah permasalahan yang perlu ditangani dengan baik. Jenis narkotika yang tidak tercantum dalam Single Convention on Narcotics Drugs tahun 1961 atau Single Convention on Psychotropics Substances tahun 1971 oleh UNODC disebut juga dengan New Psychoactive Substance atau NPS. Saat ini, NPS tidak dikontrol oleh dunia, tetapi dapat dikontrol oleh negara maupun organisasi antar negara, seperti Uni Eropa. Di Indonesia, penyalahgunaan NPS digolongkan sama dengan penyalahgunaan NAPZA. Beberapa jenis NPS yang telah terdeteksi oleh BNN sudah dimasukkan kedalam jenis narkotika. Tindakan tersebut direalisasi melalui dilampirkannya NPS kedalam Peraturan Menteri Kesehatan no 02 tahun 2017 tentang penambahan daftar lampiran UU Narkotika dan Peraturan Menteri Kesehatan Nomor 3 Tahun 2017 tentang penambahan daftar lampiran UU Psikotropika. Banyak jenis NPS di Indonesia yang belum teridentifikasi sehingga termasuk kedalam NPS yang masih dianggap lega atau biasa disebut dengan legal high. Walaupun dianggap legal, ternyata penggunaan NPS memiliki banyak efek buruk. . The Scottish Drugs Forum merangkum beberapa efek tersebut sebagai berikut: "some of the key reported harms during intoxication and comedown:

1. Overdose and temporary psychotic states and unpredictable behaviours;

2. Attendance at A\&E and some hospital admissions;

3. Sudden increase in body temperature, heart rate, coma and risk to internal organs (PMA);

4. Hallucination and vomiting;

5. Confusion leading to aggression and violence;

6. Intense comedown that can cause users to feel suicidal.

7. Use was also associated with longer term health issues:increase in mental health issues including psychosis, paranoia, anxiety, 'psychiatric complications'; depression; and physical and psychological dependency happening quite rapidly after a relatively short intense period of use (weeks)"

Dengan demikian, penyalahgunaan NPS ternyata dapat menimbulkan ancaman kesehatan, gangguan psikologis, serta mengandung ancaman bahaya lainnya. Raharjo (dalam jurnal kearifan lokal,keberfungsian sosial dan penanganan bencana) mengemukakan bahwa penyalahguna NAPZA merupakan salah satu jenis dari at risk population of social functioning. Hal tersebut berarti bahwa orang yang telah melakukan penyalahgunaan NPS juga memiliki potensi rawan dalam keberfungsian sosialnya.

Joyakin (dalam artikel penilaian keberfungsian sosial klien) mengungkapkan empat hal yang dinilai dalam keberfungsian sosial klien, yaitu kemampuan dalam memenuhi kebutuhankebutuhan sehari-hari, kemampuan dalam mengatasi masalah-masalah yang dihadapinya, kemampuan dalam menampilkan peranan-peranan sosial dalam lingkungannya, dan kemampuan dalam pengembangan diri.

Selain itu, muncul berbagai penelitian mengenai penggunaan NPS di dunia. Salah satunya adalah penelitian yang dilakukan oleh NGO bernama AddAction di Inggris meneliti bahwa sejumlah satu dari lima mahasiswa di sebuah universitas di Inggris pernah menyalahgunakan NPS. NPS marak sekali di kalangan mahasiswa. Beranjak dari paparan sebelumnya, maka timbul sebuah pemikiran untuk meneliti mengenai keberfungsian sosial seseorang yang menyalahgunakan NPS di lingkungan Universitas Padjadjaran.

Saat ini, penyalahgunaan NPS dianggap sama seperti penyalahgunaan NAPZA. Kementrian Kesehatan telah melampirkan beberapa jenis NPS sebagai narkotika, baik golongan I, golongan II maupun golongan III. Hal tersebut terlampir dalam Permenkes no 2 tahun 2017 dan Permenkes nomor 3 tahun 2017 yang mencantumkan 43 jenis NPS sebagai narkotika. Dalam dokumentasi dari UNODC, Indonesia tercatat menjadi negara yang telah menyita kethamine (jenis zat NPS) lebih dari $1 \mathrm{~kg}$ di tahun 2010 dan 2011. 


\begin{tabular}{|l|l|l|l|l|}
\hline Jurnal Penelitian \& PKM & Juli 2017 & Vol 4, No: 2 & Hal: $129-389$ & ISSN \\
\hline
\end{tabular}

Tabel 1

Negara dengan Penyitaan Kethamine melebihi $1 \mathrm{~kg}$

\begin{tabular}{|l|c|c|c|c|}
\hline & 2009 & $\mathbf{2 0 1 0}$ & $\mathbf{2 0 1 1}$ & $\mathbf{2 0 1 2}$ \\
\hline Canada & $\bullet$ & $\bullet$ & $\bullet$ & \\
\hline Cambodia & $\bullet$ & & & \\
\hline China & $\bullet$ & $\bullet$ & $\bullet$ & \\
\hline France & $\bullet$ & & $\bullet$ & $\bullet$ \\
\hline Hong Kong SAR & $\bullet$ & $\bullet$ & $\bullet$ & $\bullet$ \\
\hline Hungary & $\bullet$ & $\bullet$ & $\bullet$ & \\
\hline India & $\bullet$ & $\bullet$ & $\bullet$ & \\
\hline Indonesia & & $\bullet$ & $\bullet$ & \\
\hline Italy & $\bullet$ & $\bullet$ & $\bullet$ & \\
\hline Malaysia & $\bullet$ & $\bullet$ & $\bullet$ & $\bullet$ \\
\hline Myanmar & $\bullet$ & & $\bullet$ & \\
\hline Netherlands & $\bullet$ & $\bullet$ & $\bullet$ & \\
\hline Philippines & $\bullet$ & & & \\
\hline Singapore & $\bullet$ & $\bullet$ & $\bullet$ & $\bullet$ \\
\hline Spain & $\bullet$ & $\bullet$ & $\bullet$ & $\bullet$ \\
\hline Thailand & $\bullet$ & $\bullet$ & $\bullet$ & \\
\hline United States & & $\bullet$ & & \\
\hline Source: UNODC questionnaire on NPS, 2012, ARQ and DAINAP \\
\hline
\end{tabular}

Hal tersebut berarti bahwa di Indonesia telah beredar NPS sejak 2010, atau mungkin dari tahun sebelum 2010. BNN mengemukakan bahwa pemerintah telah mengidentifikasi sejumlah 53 NPS. Sementara itu, UNODC melalui Early Warning Advisory (EWA) on New Psychoactive Substances, Vol. 7, pada Februari 2016 telah mengidentifikasi 643 NPS yang mayoritas merupakan zat sintetis dari cannabinoid.

Di Indonesia, NPS yang banyak tersebar merupakan sintetis dari cannabinoid yang biasa dikenal dengan nama tembakau gorilla, K2, atau spice. Ada pula beberapa kasus mengenai penangkapan penyalahguna NPS tersebut, salah satunya adalah penangkapan artis A di Bandung pada 2016. BNN juga mengungkapkan beberapa bahan yang mengandung NPS sebagai berikut:

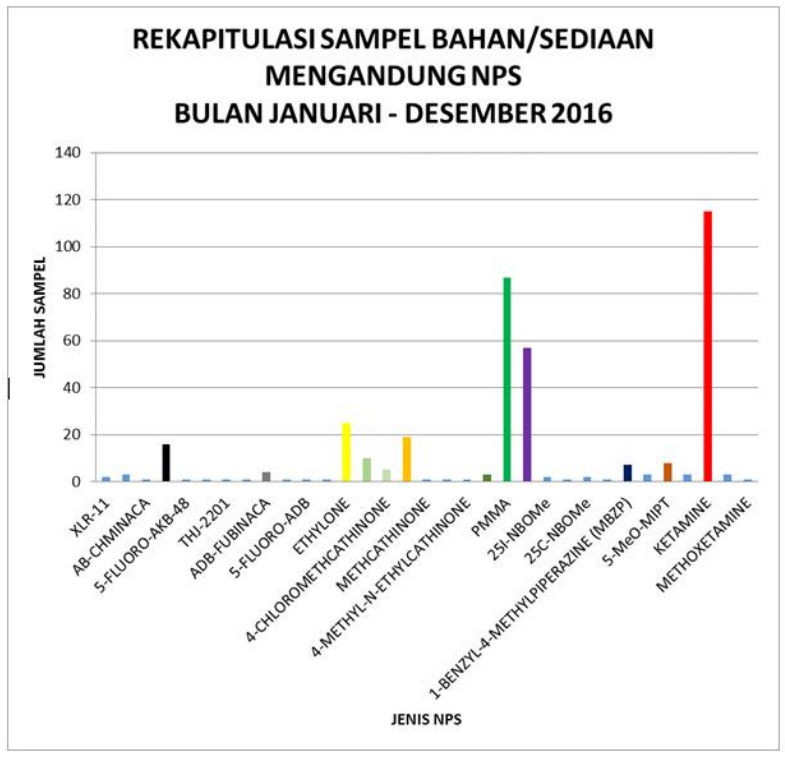

NPS adalah berbagai jenis zat yang memiliki efek yang sama dengan narkotika pada umumnya tetapi asal zat nya berbeda dan telah didesain secara kimiawi agar terhindar dari perundang-undangan. NPS memiliki berbagai macam bentuk dan zat kimia yang bermacam-macam sehingga identifikasi dari NPS membutuhkan waktu yang lama dibandingkan dengan pembuatannya.

Keberfungsian sosial berarti kemampuan seseorang untuk memenuhi kebutuhan dasarnya, menjalankan peranan dirinya dalam lingkungan sosial dan kemampuan seseorang dalam menghadapi permasalahan yang terjadi.

Joyakin mengemukakan keberfungsian sosial seseorang dapat dilihat dari 4 hal utama, yaitu:

(1) kemampuan dalam memenuhi kebutuhankebutuhan sehari-hari

(2) kemampuan dalam mengatasi masalahmasalah yang dihadapinya

(3) kemampuan dalam menampilkan perananperanan sosial dalam lingkungannya

(4) kemampuan dalam pengembangan diri

\section{Metode}

Metode yang digunakan dalam penelitian ini adalah metode kualitatif. Penelitian ini menggunakan metode kualitatif. Metode kualitatif adalah: 


\begin{tabular}{|l|l|l|l|l|}
\hline Jurnal Penelitian \& PKM & Juli 2017 & Vol 4, No: 2 & Hal: $129-389$ & ISSN \\
\hline
\end{tabular}

"Penelitian kualitatif adalah penelitian yang bermaksud untuk memahami fenomena tentang apa yang dialami oleh subjek penelitian misalnya perilaku, persepsi, motivasi, tindakan, dan lain-lain secara holistik, dan dengan cara deskripsi dalam bentuk kata-kata dan bahasa, pada suatu konteks khusus yang alamiah dan dengan memanfaatkan berbagai metode ilmiah (Moeloeng, 2007)".

Penelitian bertujuan untuk mengetahui mengenai keberfungsian sosial bagi penyalahguna NPS. Adanya fenomena mengenai penyalahgunaan NPS menjadi alasan dipilihnya kualitatif sebagai suatu metode yang digunakan untuk penelitian ini.

\section{UCAPAN TERIMA KASIH}

Penulis bersyukur kepada Allah SWT dan berbagai pihak yang telah membantu dalam proses pelaksanaan mata kuliah penelitian pekerjaan sosial. Selain itu, terima kasih kepada temanteman sesama mahasiswa yang sudah saling berbagi dan saling membantu. Tidak lupa, terima kasih kepada Ibu Dessy Hasanah SA., Dra., M.Si dan Bapak Maulana Irfan, S.Sos., M.Ikom selaku dosen pembimbing serta Bapak Dr. Santoso Tri Rahardjo, S.Sos., M.Si, dan Bapak Ishartono, Drs selaku dosen pengampu mata kuliah penelitian pekerjaan sosial.

Penulis menyadari dalam penulisan artikel ini masih memiliki banyak kekurangan. Tetapi, penulis berharap bahwa nantinya artikel ini dapat memberi manfaat bagi siapaoun.

\section{DAFTAR PUSTAKA}

Joyakin. N.d. Penilaian Keberfungsian Sosial Klien. Diakses 13 Juni 2017 dari http://media.kemsos.go.id/images/317Keberf ungsian_Sosial.pdf

Moleong, Lexy J. 2007. Metodologi Penelitian Kualitatif. Bandung: PT Remaja Rosdakarya Offset.

New Psychoactive Substance. Diakses 13 Juni 2017 dari http://www.drugwise.org.uk/ newpsychoactive-substances/

No author. 2016. NPS Menyerang Indonesia. diakses 13 Juni 2017 dari http://lampung.bnn.go.id/wp/2016/11/16/ne w-psychoactive-substance-nps-menyerangindonesia/

Raharjo, Santoso Tri. N.d. Kearifan Lokal, Keberfungsian Sosial dan Penanganan Bencana. Diakses 13 Juni 2017 dari http://repository.unpad.ac.id/22916/1/00010 -kearifan-lokal-keberfungsian-sosial.pdf

Raharjo, ST. 2015. Assessment untuk Praktik Pekerjaan Sosial dan Kesejahteraan Sosial. Bandung: Unpad Press 2015. Dasar Pengetahuan Pekerjaan Sosial. Bandung: Unpad Press. 2015. Keterampilan Pekerjaan Sosial: Dasar-dasar. Bandung, Unpad Press.

Suharto, Edi. 2005. Mebangun Masyarakat Memberdayakan Rakyat. Refika Aditama

Yuliana, Nevi. 2014. New Psychoactive Substance. Diakses 13 Juni 2017 dari http://kepri.bnn.go.id/2014/11/newpsychoactive-substances/\#

Dokumentasi lainnya

Dokumentasi mengenai legal high oleh NGO WCADA

https://www.youtube.com/watch?v=EpRsCC OGNWk\&t=1s

Dokumentasi mengenai NPS oleh NGO Addaction https://www.youtube.com/watch?v=34esF2r Z5JE

Daftar NPS yang diidentifikasi BNN. Diakses 13 Juni 2017

dari http://www.bnn.go.id/_multimedia/document /20170203/nps_2017_-_53_zat.pdf

Perundang-undangan

Permenkes no 2 tahun 2017

Permenkes no 3 tahun 2017 